\title{
The Latest Amendments of American Security Interests
}

\author{
Rongxin Zeng ${ }^{1}$ \\ ${ }^{1}$ School of Law, Jiangxi University of Finance and Economics, China \\ Correspondence: Rongxin Zeng, School of Law, Jiangxi University of Finance and Economics, China. E-mail: \\ zrx0501@gmail.com
}

Received: May 20, 2013 Accepted: June 7, 2013 Online Published: August 30, 2013

doi:10.5539/jpl.v6n3p126 URL: http://dx.doi.org/10.5539/jpl.v6n3p126

\begin{abstract}
This research paper is dedicated to the analysis of the recent revisions of security interests system in the US after the sub-prime mortgage crisis. The focus in the analysis is made on the tendencies, experiences, and advantages of the reforms and especially on the amendments of Article 9 provisions of the Uniform Commercial Code that occurred in 1998 and went into effect on July 1, 2001, and the latest modifications that occurred in 2010 and will be into effect in 2013. Without a doubt, the reforms of security interests system are important elements of the US government's response to the sub-prime mortgage crisis of 2007-2009.
\end{abstract}

Keywords: security interest, amendments, UCC, collateral

\section{Security Interest and Article 9 of the Uniform Commercial Code}

The discussion needs to start with the clarification of what exactly the security interest is and the way it has been regulated through Article 9 of the Uniform Commercial Code. Basically, it is a property interest which is formed by agreement or by operation of law on the property to secure the performance of an obligation, in the majority of cases, the payment of a debt.

The beneficiary is provided with preferential rights in the disposition of secured assets and these rights are different depending on the model of security interests. But the holder of the security interest is enabled to seize, and to sell, the property to discharge the debt that the security interest secures (Note 1).

In accordance with the Article 9, security agreement creates security interest, and based on such agreement the debtor grants a security interest in the debtor's property as collateral for a loan or other obligation (Note 2).

What is the meaning of Article 9 of the Uniform Commercial Code? It was developed to regulate security interests in personal property (as opposed to real property) and establishes a unified concept of a security interest as a right in a debtor's property that secures payment or performance of an obligation. It needs to be pointed out that a holder obtains a right to take a remedial action towards the property, if certain events happen, for instance, the non-payment of a loan. The property may be taken by the creditor to meet the obligation. Eventually, the property will be sold at a public auction or through a private sale.

But it has to be emphasized that Article 9 is particularly related to personal property and fixtures(i.e., personal property attached to real property). As for the real property, it is regulated by local laws which are different from state to state.

There are two recent initiatives of Article 9 known. One of them, a major amendment took place on July 1, 2001, before the financial crisis. The changes were related to transactions in which personal property is used as security for a loan or extension of credit. In addition, the further amendments were proposed in 2010 and some of these have been already adopted by several states, but the uniform effective date of these amendments is July 1, 2013 .

\section{The Role of Securitization in the Crisis and the Central Bank}

\subsection{The Role of Securitization in the Crisis}

According to D'Arista (Note 3), financial crisis have made a substantial negative impact over a number of financial innovations including packaging of loans into securities. As D'Arista states, before the crisis there were two trends: the explosive growth of sub-prime mortgages and credit derivatives and the transformation of the U.S. Financial structure from a system based bank lending to one that is based on highly speculative securities markets. 
Between 1977 and 2007, the traditional U.S. bank-based system was totally changed because the share of total credit-market assets accounted for by GSEs, mortgage pools, and asset-backed securities issuers has increased up to 20.5 percent and at the same time banks' share has significantly decreased. Basically it was the process of erosion of the traditional U.S. bank-based system.

The outcome of this erosion in a form of the sub-prime crisis was not surprising. As a result, a number of reforms are required to improve the situation on the financial market, such as:

- $\quad$ "Higher Capital Requirements.

- Adequate Disclosure, because the problems that caused damage to financial markets and households can't be addressed only by capital

- Standardizing Contracts and Reporting Trades.

- Improved Lending Standards.

- Covered Bonds." (Note 4)

2.2 The Role of the Central Bank

As the most influential financial regulatory agency in the US, the central bank has a power to revise the interest rates. It is known that many traditional regulative tools were applied and many new unprecedented ones to cope with financial system breakdown after the sub-prime mortgage crisis.

\section{Revisions of Article 9 of the Uniform Commercial Code that Were Made on July 1, 2001}

It has to be clarified that Article 9 regulates secured transactions in various forms. It gives the rules that regulate any transaction, other than finance lease, maintaining the creditor's interest in a debtor's personal property. This Article underwent significant revisions both in terms of its scope and requirements in 2001. The major revision of Article 9 happened on July 1, 2001 when it became uniform effective in all 50 states and the District of Columbia.

The benefits provided by those revisions made in 2001 include the benefits in commercial transactions. Commercial creditors may benefit from new provisions of Article 9, particularly if they plan to sell to customers that do not meet their normal credit standards. As a result, the competitive advantage of providing credit terms with less risk could be gained by the seller (Note 5).

It also decreases the risks for the seller/creditor, because the seller/creditor has the ability to repossess and then resell the products if payment default happens. In the cases of buyer's bankruptcy, the seller/creditor (secured under Article 9) has a priority claim over all unsecured creditors and some other secured creditors. The major requirement for the seller/creditor in this case is to follow all the steps in the process and to complete the appropriate documentation (Note 6).

\section{Comparison of the Revisions of Article 9 of the Uniform Commercial Code: 2001 vs. 2013}

It has to be pointed out that the recent revision has not created any fundamentally changes into the law of secured transactions but these revisions help to clarify and modernize the existing version of this regulation.

The article "Changes to UCC Article 9 Effective July 1, 2013" (2012) indicates that the latest version of Article 9 will have a substantially expanded scope. Additional things "deposit accounts," "credit card receivables," "payment intangibles," "electronic chattel paper" and "supporting obligations"(by example, obligations, such as guaranties and letters of credit, that support the payment of an obligation in which a security interest has been granted) will be included. Besides it, the new version will allow to simplify legal issues arising under securitizations, although its ramifications will also be felt in secured lending and other areas.

In addition, the new version of Article 9 covers expanded and more flexible methods to improve security interests. The legislation will provide for perfection by "control" and for automatic perfection of security interests in certain categories of collateral. Security interests in deposit accounts, letter-of-credit rights and electronic chattel paper will be subject to perfection by control. The steps necessary to achieve control under Revised Article 9 will, however, vary depending on the type of property involved.

Besides, under the revised Article 9 the rules of the filing of financial statements will be easier. In additional, the rules of conflict of laws regarding security interests perfected though filing will be simplified as well. Author/authors of the article "Changes to UCC Article 9 Effective July 1, 2013" (2012) explain that on the grounds of Current Article 9, the perfection of security interests in property (other than "mobile" property) is completed by filing in the court that the property is located, while the perfection in intangible collateral, such as "accounts" and "general intangibles" is completed by filing in the jurisdiction in which the debtor is located. Revised Article 9 will unify these rules by providing, in almost all cases, for filing in the jurisdiction in which the debtor is located, but not the location in which the collateral is located. 
Another advantage of the new reformed version of Article 9 is the opportunity to determine the "location" of most types of debtor. Under Current Article 9, a debtor other than a natural person is deemed to be located at its workplace, if it has one, or at its "chief executive office," if it has more than one. In a corporate world characterized by large multinationals and frequent mergers and restructurings, to determine which office is the "chief executive office" can be almost impossible - but the penalty for an incorrect judgment in this regard can be a worthless security interest.

According to Warner (Note 7), improvement is also made in terms of the introduction of the new standard for measuring whether a financing statement sufficiently lists the name of the debtor. The new legal standard, coupled with strict search logic standards being adopted by filing offices, should make it much easier to challenge the perfection of a security interest on the basis of minor errors in the debtor's name (Note 8).

Uniform Commercial Code (UCC) Article 9 deals with all transactions (other than a finance lease) that maintain the creditor's interest in a debtor's personal property. The debtor can be an individual or any business entity, ranging from a registered corporation to a single proprietorship. A decade later, a Review Committee was appointed by the American Law Institute (ALI) and the Uniform Law Commission (ULC) to review the practical application of Article 9. In 2010, this Committee suggested several amendments related to filing issues and other matters that had arisen since the 2001 revision went into effect. This was not intended as a major overhaul of the Article, but rather as recommendations for changes to sections that appeared to be creating significant problems in practice.

The ULC recommended the July 1, 2013 nationwide effective date, along with a five-year transition period.

The most important provisions of the revised Article 9 in 2013 version are as follows:

(1) UCC \$9-102(a) (68) in 2001 version provides that the name on the "public record" is the correct name of the organization who makes a financing statement. While the new version formulates that the exact name is now the name registered on a special kind of document-public organic record accessible to the public inspection, including documents filed with or by the state to form an organization, for instance, articles of incorporation, agreement as to limited partnership. This revision counts among the most important amendment in the new version. It aims to provide a more reliable certainty and safety as to the consistency of the name of debtor on the financing document and the exact name required by UCC 9 .

(2) In order to determine whether a secured creditor has control of electronic chattel paper, the of the 2001 version required to make an extensive test from six aspectsest. In the new version, the extensive test of six-factor has been retained. Besides, the new version adds a general requirement that the system used to certify the transfer of the electronic chattel paper should "reliably establish the secured party as the person to whom the chattel paper was assigned". Therefore, the new version of the UCC \$9-105 clarifies and reinforces the rules relating to "control" of electronic chattel paper, and provide more flexible and reliable ways for secured parties by developing more reliable systems to monitor and control these documents.

(3) As to UCC \$9-316, the 2001 version, provided that the security interests that attach prior to a debtor's move to another state remain perfected for four months after the move in the new state.

While the 2013 Version adds a new subsection (h) which provides that the pursuit of the perfection of security interests newly acquired that attach within four months after the debtor moves, so long as the secured party has taken steps that would have perfected the security interest in the original state of the detor. The perfection of the security interests extends to the expiration of the period of four months. A new subsection (i) was also added. It provides for automatic perfection of security interests that are bound within four months after securing a new debtor in another member state of an existing security agreement with the original debtor. Again, this applies as long as the secured creditor has adopted measures that have perfected the security interest against the original debtor. As a result, the revised version of UCC \$9-316 makes it more likely that a secured creditor will remain enforceable in case of a movement of a borrower to another state or integration with a debtor in another state.

(4) In common with §9-102(a) (68), UCC § 9-503 provides the exact name of the debtor should be involved in the financing account, even if the variations of individuals' or organizations' names is mineur. This strict requirement has made it difficult for the secured parties to identify the propre name of the detor on the financing statement.

In the 2013 version, this section imposes the registered organizations to select an exact name as mentioned in \$9-102(a) (68). However, if detors are natural persons, they have two different options. State legislatures can choose the solution that best suits the constituents needs. 
On the one hand, there exists an "Only If" Option: If the debtor has a driver's license or other identification of the state, which remains unexpired and valid, his financing statement can choose the name used on such kind of documents. If the debtor does not have such kind of unexpired and valid state ID, the secured creditors can use the debtor's first personal name and surname.

b. On the other hand, there exists also a "Safe Harbor" Option. If detor's name satisfy one of the following condition, it can be used on financing statement: (a) the detor's individual name determined by the laws of the State, (b) the surname and the first personal name of the debtor, or (c) the names remaining valid on state legal ID, such as the driver's license or other state ID.

(5) In the old 2001 version, UCC \$9-516 provided that the information as to the type of organization, jurisdiction and organizational ID number of the detor should be included in the financing statement.

While the new 2013 version revises the requirements as to the information provided on the financing statement. The Uniform Law Commission determined that the burden of providing the information was not worth the benefit, considering the reality that it was related barely to registered organizations and the fraudulent usage of duplicate name(s) or deceptively similar name(s) have already been regulated by states laws. For this reason, the requirements as to the information of the three pieces mentioned before have been canceled in the new version.

So far, 29 states have enacted the 2010 revisions to UCC Article 9, and 6 states plus the District of Columbia have introduced the legislation. ("Changes to UCC Article 9 Effective July 1, 2013", 2012)

Table 1. States that have enacted revised UCC Article 9

\begin{tabular}{lclc}
\hline Colorado & Kentucky & New Hampshire & South Dakota \\
\hline Connecticut & Louisiana & North Carolina & Tennessee \\
Florida & Maryland & North Dakota & Texas \\
Hawaii & Michigan & Ohio & Virginia \\
Idaho & Minnesota & Oregon & Washington \\
Indiana & Nebraska & Puerto Rico & West Virginia \\
Iowa & Nevada & Rhode Island & Wisconsin \\
Kansas & & & \\
\hline
\end{tabular}

Table 2. States that have introduced revised UCC Article 9

\begin{tabular}{llcc}
\hline Alabama & Massachusetts & Oklahoma & Pennsylvania \\
\hline District of Columbia & New Mexico & Illinois & \\
\hline
\end{tabular}

\section{Criticism of Revisions of Article 9 the Uniform Commercial Code}

Warner (Note 9) explains that Article 9 revision creates some difficulties in terms of security interests to be avoided in bankruptcy. This researcher mentions the following strong sides of the revised version of Article 9:

\subsection{The Strong-arm Power and Financing Statement Errors}

The trustee in bankruptcy is given the status of a judicial lien from the time of petition. Such legal treatment allows the trustee to avoid the competition of any security interest fixed by Article 9. In other words, the rights of creditors beneficiary of any security interest fixed by Article 9 would be subordinated to the rights of such a lien creditor. Under Revised Article 9, as under prior law, this means that the trustee can avoid a security interest that has not yet been perfected as of the date of petition. The revised version of Article 9 clearly reduces the probability of committing fatal errors in the financial statements both by reducing the number of required filings and by reducing the types of errors that may make the financing statement ineffective. Regarding the content of financial statement, only errors in the debtor's name, the name of the secured creditor or the indication of the collaterals can make the financing statement ineffective as to lien creditors - and therefore trustees - in case of bankruptcy (Note 10). 
Of these three articles, only the name of the debtor is likely to provide much opportunity for lien avoidance. Because revised Article 9 significantly relaxes the burden of information required as to the collateral and even allows "all assets" filings, it will become much more difficult for trustees to avoid security interests on the grounds of errors as to collateral description. The ability of the trustee to avoid security interests on the grounds of errors in the financing statement is moreover reduced by new revisions. According to this article, errors cannot make the security interest unperfected, unless the error "make[s] the financing statement seriously misleading." (Note 11)

\subsection{The Correct Name}

On the whole, revised Article 9 stipulates clearer rules for determining the correct use of the name for a debtor on a financing statement. For registered organizations like companies, limited partnerships and limited liability companies, the financing statement must indicate the exact name of the debtor as it appears in the public records of the jurisdiction in which the debtor was organized. For other debtors, such as natural persons and most unregistered organizations, the financing statement must show the "individual or organizational name" of the debtor. (Note 12)

But the researchers also found that even if these rules make it very simple to identify the correct name for registered organizations, the new version of the Article 9 does not attempt to resolve many problems concerning the human names. For example, the revised article 9 does not clearly stipulate whether the full legal name is required or a nickname or widely used alias is enough.

While the previous manual search systems could accommodate some variation in human names, the modem computerized search logic used by the filing offices has little tolerance for variation. Therefore, courts interpreting the revision will have to resolve these issues with regard to the limitations of computer-based classification systems (Note 13).

\subsection{The "Seriously Misleading" Standard}

An error relative to the name of the debtor is not fatal unless it makes the financing statement seriously misleading. Under the previous regulations, the courts determined whether an error was seriously misleading by asking whether a hypothetical "reasonably diligent searcher" could discover the erroneous filing. Accordingly, the standard of human judgment was relevant, and being close was often good enough. For name errors, the revision replaces this reasonableness standard with a precise standard based on the computerized search logic used by the relevant filing office. According to the new standard, an error of name is fatal if a search under the correct name, using the filing office's standard search logic, would not disclose the financing statement (Note 14).

\section{Conclusion}

The analysis taken from a number of literary and Web sources allows to make a conclusion that the recent revisions of Article 9 provisions of the Uniform Commercial Code of 1998-2001 and 2010-2013 appear to be effective, although some changes may create certain difficulties, such as those described in the 'Criticism of revisions' part of the present paper. As for the latest revision, it needs to be sum up that it has not created any fundamentally changes into the law of secured transactions but amendments were developed specifically to modernize the existing regulations and the developers have fulfilled their task.

Overall, the research of the experiences of Article 9 revisions demonstrate significant improvements that were introduced into security interest system in the US after the sub-prime mortgage crisis of 2007-2009. Despite the obvious advantages, critics have found a number of weaknesses that need to be corrected in the future revisions.

\section{References}

Barrell, R., \& Holland, D. (2010). Fiscal and Financial Responses to the Economic Downturn. National Institute Economic Review, 211, R51.

Barrell, R., Fic, T., \& Holland, D. (2009), Evaluating policy reactions to the financial crisis. National Institute Economic Review, 207, 39-42.

Changes to UCC Article 9 Effective July 1, 2013. Retrieved September 20, 2012, from http://www.credit-to-cash-advisor.com/Articles/CommercialLaw/UCCArticle-9

D'Arista, J. (2010). Simplifying Securitization with a Better System, the Economy Can Have Plenty of Credit without the Outlandish Risks and Excess Banker Profits. The American Prospect, 21(5), A18.

Elliott, L. (2011). Global financial crisis: five key stages 2007-2011. Retrieved August 7, 2011, from http://www.guardian.co.uk/business/2011/aug/07/global-financial-crisis-key-stages. 
Hendrickson, J., \& Nichols, M. (2011). How Do Predatory Lending Laws Impact Bank Performance? Academy of Banking Studies Journal, 10(1), 1.

Kalembka, L. (n. d.). Revised Article 9 of the Uniform Commercial Code: An Introduction, Mar-26-2008. Retrieved September 20, 2012, from http://corporate.findlaw.com/business-operations/revised-article-9-of-the-uniform-commercial-code-an-intr oduction.html.

Scarborough, M. (2010). Securities Blanket: Banks Thinking about Securities Brokerage Should Consider the Experience and Advice of Several Mid-Size Banks Already in the Business. ABA Banking Journal, 102(12).

Secured Transactions and UCC 9. Retrieved September 20, 2012, from http://www.credit-to-cash-advisor.com/Articles/CommercialLaw/SecuredTransactionsandUCC9

Swagel, P. (2009). The Financial Crisis: An Inside View. Brookings Papers on Economic Activity (p.1).

Warner, G. (2002). Using the Strong-Arm Power to Attack Name Errors under Revised Article 9. (Selected Topic). Business Credit, 104(3), 63.

\section{Notes}

Note 1. Scarborough, M. (2010) Securities Blanket: Banks Thinking about Securities Brokerage Should Consider the Experience and Advice of Several Mid-Size Banks Already in the Business, ABA Banking Journal, Vol. 102, No. 12.

Note 2. Scarborough, M. (2010) Securities Blanket: Banks Thinking about Securities Brokerage Should Consider the Experience and Advice of Several Mid-Size Banks Already in the Business , ABA Banking Journal, Vol. 102, No. 12.

Note 3. D'Arista, J. (2010) Simplifying Securitization with a Better System, the Economy Can Have Plenty of Credit without the Outlandish Risks and Excess Banker Profits. The American Prospect. 21 (5), p. A18.

Note 4. D'Arista, J. (2010) Simplifying Securitization with a Better System, the Economy Can Have Plenty of Credit without the Outlandish Risks and Excess Banker Profits. The American Prospect. 21 (5), p. A18.

Note 5. Kalembka L. Revised Article 9 of the Uniform Commercial Code: An Introduction, Mar-26-2008,

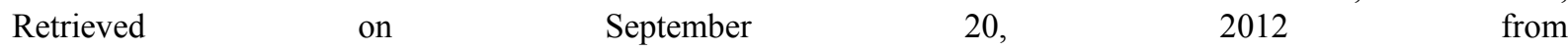
http://corporate.findlaw.com/business-operations/revised-article-9-of-the-uniform-commercial-code-an-introduct ion.html.

Note 6. Kalembka L. Revised Article 9 of the Uniform Commercial Code: An Introduction, Mar-26-2008,

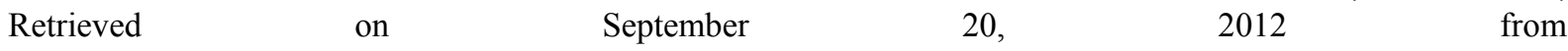
http://corporate.findlaw.com/business-operations/revised-article-9-of-the-uniform-commercial-code-an-introduct ion.html.

Note 7. Warner, G. (2002) Using the Strong-Arm Power to Attack Name Errors under Revised Article 9. (Selected Topic). Business Credit. 104 (3), p.63.

Note 8. Warner, G. (2002) Using the Strong-Arm Power to Attack Name Errors under Revised Article 9. (Selected Topic). Business Credit. 104 (3), p.63.

Note 9. Warner, G. (2002) Using the Strong-Arm Power to Attack Name Errors under Revised Article 9. (Selected Topic). Business Credit. 104 (3), p.63.

Note 10. Warner, G. (2002) Using the Strong-Arm Power to Attack Name Errors under Revised Article 9. (Selected Topic). Business Credit. 104 (3), p.63.

Note 11. Warner, G. (2002) Using the Strong-Arm Power to Attack Name Errors under Revised Article 9. (Selected Topic). Business Credit. 104 (3), p.63.

Note 12. Warner, G. (2002) Using the Strong-Arm Power to Attack Name Errors under Revised Article 9. (Selected Topic). Business Credit. 104 (3), p.63.

Note 13. Warner, G. (2002) Using the Strong-Arm Power to Attack Name Errors under Revised Article 9. (Selected Topic). Business Credit. 104 (3), p.63.

Note 14. Warner, G. (2002) Using the Strong-Arm Power to Attack Name Errors under Revised Article 9. (Selected Topic). Business Credit. 104 (3), p.63. 


\section{Copyrights}

Copyright for this article is retained by the author(s), with first publication rights granted to the journal.

This is an open-access article distributed under the terms and conditions of the Creative Commons Attribution license (http://creativecommons.org/licenses/by/3.0/). 